\title{
An Empirical Study on the Relationship between Corporate Governance and Technical Innovation
}

\author{
Xiaoqin Wang*, Zhi Geng, Qiang Yang \\ Tianjin University of Technology, Tianjin, China \\ *13821670595@163.com
}

Keywords: Corporate Governance, Technological Innovation, Empirical Research

\begin{abstract}
The paper empirically studies the corporate governance under the background of technological innovation based on fixed effect panel regression model. The structure is as follows: ownership concentration, equity checks and balances, executive currency remuneration and senior management shareholding ratio are positively correlated with technological innovation, and the proportion of independent directors the number of meetings held during the year in the shareholders' meeting and the board of directors were negatively related to technological innovation. Finally, it puts forward suggestions to improve the awareness of technological innovation of enterprises and improve the corporate governance structure.
\end{abstract}

\section{Introduction}

Independent innovation plays an important role in building national innovation system, driving economic development and realizing transformation and upgrading. In recent years, our government has increased the investment in science and technology, but the effect is not obvious. Data shows that external dependency technology in China is as high as $50 \%$ above. As the main body of independent innovation enterprises, how to improve their technology innovation ability is a big challenge which is in urgent need to cope with under the economically new normal. Corporate governance, as a foundation for enterprise technology innovation system, through the governance structure reform to promote technological innovation, definitely plays a decisive influence on technology innovation, which is also an important approach to improving the enterprise vitality and performance. Scholars have studied the influence of corporate governance on technological innovation from various angles.

Internal governance structure of the company:

RENYUNHAI (2010) collected data of 676 manufacturing listed company on 2008-2010 A-share motherboard, using multiple regression method and empirically studying the relationship between ownership structure and $R \& D$ input, and found some checks and balances equity concentration, institutional investors and $R \& D$ input is positively relevant to improving $R \& D$ input, but state-owned shares is negatively related to the R\&D input. Feng Gen and WenJun (2008) taking 343 listed companies during 2005-2007 as samples, on the basis of equity structure, considering the executives shareholding and the board of directors on the impact of technology innovation, and using multiple regression method, empirically found that equity concentration and enterprise technology innovation is "inverted $U$ " relationship and proportion of state-owned shares is negatively related to the enterprise technology innovation; institutional ownership proportion and independent director system is positively related to technology innovation.

To sum up, influence on technology innovation, corporate governance is based on the traditional principal-agent theory research. The perfect corporate governance structure through effective supervision and incentive mechanism, guiding the shareholders, the board of directors, managers or other stakeholders effective configuration of innovation resources arouse the inner motive power of enterprise independent innovation. 


\section{Research Hypotheses}

Equity structure and technological innovation.

The ownership structure is the basis of the arrangement of corporate governance system, which determines the power distribution of the interests in the company and influences the technological innovation decision of the company.

Equity concentration: although technical innovation is very important, it requires a high investment in research and development, however, with great uncertainty. Once the innovation fails, the $R \& D$ investment will constitute the sunk cost of the enterprise. Even if innovation succeeds, its benefits will take a long time to materialize. Additionally, technology innovation activities are highly professional, if detailed technical innovation project, also alleged leak trade secrets, passed an important signal to competitors, so technology innovation has a serious information asymmetry. Under the decentralized equity structure, considering the supervision cost, small and medium shareholders are reluctant to supervise the management behavior of executives, especially the specialized innovation behavior, which is easy to contribute to "insiders" control. Consequentially, dispersed ownership structure have a negative impact on the technology innovation. With regard to highly concentrated ownership structure, large shareholders have enough power to supervise the innovation behavior of executives, so that they act according to the interests of shareholders out of respect for enterprise core competitiveness and long-term development, big shareholders will take effective action to ensure the efficient input and output of innovation project so highly concentrated ownership structure is conducive to technological innovation. Therefore, hypothesis H1: equity concentration is positively correlated with technological innovation.

Equity checks and balances. Since La Porta, etc. (1999) found that large shareholders is a common phenomenon, rather than the dispersed ownership structure. corporate governance focus then shifted from the first kind of principal-agent problems to the second category of principal-agent problems, namely the issues about the major shareholders encroach on the interests of minority shareholders. In the equity structure of "dominant" the board of directors, the appointment of the senior executives is mainly controlled by the largest shareholder, where the shareholder and executive may even conspired to transfer the resources of listed companies to the enterprise under their own control. Xiao-bao song and liu xing (2007) analyzes the conflict of shareholders to the impact of technology innovation, finding in the face of uncertainty of technology innovation and the information asymmetry, big shareholders have stronger motivation to encroach on minority shareholders interests [10]. As a conclusion, "equity checks and balances theory" believe that several big shareholders share control system can effectively restrain large shareholders, contributing to the protection of rights and interests of minority shareholders. Hence, the paper puts forward hypothesis H2: equity checks and balances is conducive to technological innovation.

The number of board meetings one year: the shareholders' committee is the highest authority of the company, the board of directors is the executive organ of shareholders, and board of supervisors is shareholders' supervising institution. They all represent the interests of the shareholders. Considering the company long-term strategic development, the encouragement for enterprises to carry out technical innovation is of considerable significance. Therefore, the paper put forward hypothesis H3: the number of meetings of shareholders, board of directors and board of supervisors is positively correlated with technological innovation.

\section{Empirical analysis of the relationship between corporate governance and technological innovation}

\subsection{Sample collection and index selection}

\subsubsection{Sample collection}

The data in this paper are all from annual database of listed companies. Which collected 
2010-2010 a-share listed companies three related data of 760 samples.

\subsubsection{Index selection}

Technological innovation: there are many ways to measure the technological innovation of enterprises. One is to invest in technology innovation, such as the use of scientific and technological personnel, research and development funds or r\&d intensity. The other is to use the enterprise innovation output to express. If use new product output value, new product production rate or patent quantity to say, this article utilize: research and development intensity $=r \& d$ fund/gross income $x$ $100 \%$.

The board of directors: for the majority of the literature, the proportion of independent directors and the number of meetings of the board of directors, board of supervisors and general meeting of shareholders will be taken as the supervision mechanism of the board of directors on behalf of shareholders.

Control variables: for high investment, high risk and delay of earnings, technical innovation has high requirement on financial cash adequacy in the current period. The better the growth of the enterprise, the stronger the profitability of the future the stronger the enterprise will be in technological innovation, so the growth, scale and financial leverage will be used as the three control indicators.

\subsection{Empirical analysis}

Panel of technological innovation in table 2 for corporate governance and fixed effects model of regression results, because all Hausman test negative, model (1) the ownership concentration and positively related to technology innovation, that the more concentrated the stake, shareholders are increasingly pay attention to the long-term development of the company, through the technological innovation into seeking promotion enterprise's core competitiveness. Model (2) find balances equity is negatively related to the technology innovation, it is because we are using the $\mathrm{Z}$ index which is inverse indicator, the greater the value shows, the weaker the equity balance ability is. Therefore, we believe that hypothesis $\mathrm{H} 2$ are met. Model (3) found that the proportion of independent directors was negatively correlated with technological innovation, contrary to hypothesis H4; The model (4) indicates that the number of three meetings is negatively correlated with technological innovation, and is not consistent with the hypothesis H3. The reason may be related to the institutional defects of our shareholders' meeting, board of directors and board of supervisors. By a representative of the shareholders and the staff of the board of supervisors of the supervisors, the choice and rewards were determined by the controlling shareholder or executives, so expect the supervision of higher levels of illegal behavior can in fact be empty generalization and formalization. Shareholders' meeting is the dominate approach for small and medium shareholders to participating in corporate governance. However, small and medium-sized shareholders, from the perspective of supervision costs and benefits, mostly adopt free-riding behavior and give up the right of supervision. Therefore, it is of great impossibility that the system defects of these three will contribute to the negative correlation between the proportion of independent directors and the number of meetings and the technological innovation.

Table 1 Basic statistics of indicators $n=3700$

\begin{tabular}{|c|c|c|c|c|c|c|c|c|}
\hline \multirow[b]{2}{*}{$\begin{array}{l}\text { Index } \\
\text { Statistic }\end{array}$} & \multirow{2}{*}{$\begin{array}{l}\text { R\&d Intensity } \\
\text { of } \\
\text { Technological } \\
\text { Innovation }\end{array}$} & \multicolumn{2}{|c|}{ Ownership Structure } & \multicolumn{2}{|c|}{ Board of Directors } & \multicolumn{3}{|c|}{ Control Variable } \\
\hline & & $\begin{array}{l}\text { Ownership } \\
\text { Structure } \\
\text { Concentration }\end{array}$ & $\begin{array}{l}\text { check-and-balance } \\
\text { ownership structure }\end{array}$ & $\begin{array}{l}\text { Proportion } \\
\text { of } \\
\text { Independent } \\
\text { Directors }\end{array}$ & $\begin{array}{l}\text { Number } \\
\text { Three }\end{array}$ & $\begin{array}{l}\text { Financial } \\
\text { Leverage }\end{array}$ & Growth & Scale \\
\hline Mean & 0.59 & 62. . 04 & 3.50 & 35.34 & 7.55 & 33.45 & 56. 43 & 21.65 \\
\hline $\begin{array}{l}\text { Standard } \\
\text { Deviation }\end{array}$ & 3. 59 & 15. 20 & 5. 42 & 5. 41 & 8. 56 & 21.22 & 173.94 & 0.98 \\
\hline Minimum & 119.64 & 10.37 & 1.17 & 20 & 0 & 0.73 & -97.54 & 13. 74 \\
\hline Махітит & 0 & 94.48 & 86.85 & 66.67 & 41.02 & 109.46 & 6219.67 & 25.84 \\
\hline
\end{tabular}


Table 2 Empirical Results of the Fixed Model of Corporate Governance and Technology Innovation Panel

\begin{tabular}{|c|c|c|c|}
\hline & Technological Innovation 1 & $\begin{array}{l}\text { Technological } \\
\text { Innovation2 }\end{array}$ & $\begin{array}{l}\text { Technological } \\
\text { Innovation3 }\end{array}$ \\
\hline $\begin{array}{ll}\text { Ownership } & \text { Structure } \\
\text { Concentration } & \end{array}$ & $0.004 \star$ & & \\
\hline $\begin{array}{l}\text { check-and-balance } \\
\text { ownership structure }\end{array}$ & & $-0.005 \star \star \star$ & \\
\hline $\begin{array}{l}\text { Proportion of Independent } \\
\text { Directors }\end{array}$ & & & $-0.016 * \star$ \\
\hline Number Three & & & $-0.007 \star \star$ \\
\hline Financial Leverage & -0.012 & & \\
\hline Growth & $-0.001 \star \star$ & $-0.001 \star \star$ & $-0.001 \star \star$ \\
\hline Scale & 0.016 & 0.015 & 0.014 \\
\hline Hausman & -9.35 & -6.14 & -9.23 \\
\hline$N$ & 3700 & 3700 & 3700 \\
\hline
\end{tabular}

\section{Main Conclusions and Policy Implications.}

This paper has collected 2013-2015 a-share listed companies related data of 760 samples, using fixed effect panel regression model empirically the relationship between corporate governance and technological innovation, and found that equity concentration, equity checks and balances, monetary compensation of executives and senior executives shareholding positively related to the technological innovation, the proportion of independent directors, the shareholders meeting, the board of directors and board of supervisors years at times is negatively related to the technology innovation, therefore, this study put forward the following Suggestions:

Enterprise technology innovation consciousness must be improved and promote the corporate governance structure. Independent innovation plays an important role in the construction of national innovation system. The main reason tends to corporate executives lack of forward-looking strategic consciousness, but only pay attention to profits in short run, not willing to go all out to perform technical innovation. In a conclusion, it is of great significance to take appropriate checks and balances and moderate concentration of ownership structure.

\section{References}

[1] Ren Haiyun. Empirical research on the relationship between ownership structure and enterprise R\&D -- based on data analysis of listed companies in a-share manufacturing. Chinese soft science, 2010.

[2] Feng Genfu, Wen jun. Empirical analysis on the relationship between corporate governance and technological innovation in Chinese listed companies. China's industrial economy, 2008(7): 91-101.

[3] Luo Mingxin, Ma Qinhai, Hu Yanbin. Political association and enterprise technology innovation performance -- research on the intermediary role of R\&D investment. Scientific research, 2013, 31 (6) :938-947.

[4] Laportar, Lopez-De-Silaned Florencio, Shleifer A, et al. Investor protection: origins, consequences, and reform. NBER Working Paper No. 7428,1999. 